A Journal of Culture, English Language, Teaching \& Literature ISSN 1414-3320 (Print), ISSN 2502-4914 (Online)

Vol. 19 No.2; December 2019

Copyright (C) Soegijapranata Catholic University, Indonesia

Developing Reading Materials Based on the Student's Multiple Intelligence Types for Junior High School Students

${ }^{1}$ Hanie Ika Setyowati and ${ }^{2}$ Sugirin

${ }^{12}$ English Language Study Program, Graduate School Program, Yogyakarta State University, Yogyakarta, Indonesia

email: ${ }^{1}$ haniesetyawati@gmail.com; ${ }^{2}$ sugirin@uny.ac.ic

Received: 26-03-2018

Accepted: 29-02-2019

Published: 3-12-2019 


\title{
Developing Reading Materials Based on the Student's Multiple Intelligence Types for Junior High School Students
}

\author{
${ }^{1}$ Hanie Ika Setyowati and ${ }^{2}$ Sugirin \\ 1haniesetyowati@gmail.com, ${ }^{2}$ sugirin@uny.ac.id \\ 1,2English Language Study Program, Graduate School \\ Program, Yogyakarta State University, Yogyakarta Indonesia
}

\begin{abstract}
Students are unique with their characteristics and differences. In line with the current learning paradigm, learnercentered paradigm, teaching and learning process places greater emphasis on individuality. One of the differences is multiple intelligence types possessed by all individuals resulting in various ways of learning. Learning materials, one of the learning resources, ideally have to accommodate the students' multiple intelligence types. However, the current learning materials contain neither sufficient reading texts nor tasks fostering their multiple intelligence types that happen in every classroom. Thus, this research intends to develop reading materials based on multiple intelligence to accommodate students' intelligence. This research belongs to research and development of which steps are conducting a needs analysis, developing the product, getting an expert judgement, trying-out the materials and revising the product (Gall, Gall \& Borg, 2007). In order to develop the appropriate reading materials that meet the students' needs, a needs analysis was initially conducted. The needs analysis was conducted in five junior high schools in Magelang district including state and private schools. The data of the needs analysis were obtained by distributing questionnaires which were used as the consideration in developing the materials. Then, the materials developed were validated by material and learning experts before being tried out at SMP N 1 Windusari, Magelang to complete and to perfect the materials. From the data analysis, the average score of the appropriateness of the content, the language, the presentation and the design of the materials was 3.54 which was classified as "very good" and "appropriate" to be implemented. Furthermore, the result indicated that the materials also fulfilled the criteria of good materials, for instance, considering that students are different. Thus, teachers and educational stakeholders should develop learning materials
\end{abstract}


catering to the students' multiple intelligence types to accommodate their differences.

Key words: reading materials, differences, multiple intelligence

\begin{abstract}
Abstrak: Setiap siswa merupakan individual yang unik dengan karakteristik dan perbedaan masing- masing. Sesuai dengan paradigma pembelajaran saat ini, yakni pembelajaran yang berpusat pada siswa, kegiatan belajar mengajar lebih menekankan pada individualitas. Salah satu perbedaan pada siswa adalah tipe kecerdasan majemuk yang menghasilkan berbagai aktivitas pembelajaran. Materi pembelajaran sebagai salah satu sumber belajar harus mengakomodasi semua jenis kecerdasan siswa. Namun, materi pembelajaran yang digunakan saat ini tidak memiliki materi membaca yang memadai atau latihan yang memfasilitasi berbagai jenis kecerdasan majemuk siswa. Sehingga, penelitian ini bermaksud untuk mengembangkan materi pembelajaran membaca berbasis kecerdasan majemuk untuk mengakomodasi perbedaan-perbedaan siswa. Penelitian ini merupakan penelitian dan pengembangan dengan mengadaptasi langkah-langkah penelitian dan pengembangan oleh Gall, Gall $\mathcal{E}$ Borg (2007) yang meliputi analisis kebutuhan, pengembangan produk, penilaian ahlu, uji coba dan revisi produk. Agar dapat menghasilkan materi pembelajara yang sesuai dengan kebutuhan siswa. Analisis kebutuhan dilakukan di lima sekolah menengah pertama di Kabupaten Magelang meliputi sekolah negeri dan swasta. Data analisis kebutuhan yang diperoleh dengan menyebarkan angket sebagai pertimbangan saat mengembangkan materi pembelajaran. Kemudian, materi yang dikembangkan divalidasi oleh ahli materi dan pembelajaran sebelum dicoba di SMP N 1 Windusari, Magelang untuk melengkapi dan menyempurnakan materi.Berdasar analisis data dari penilaiain ahli maupuun uji coba materi pembelajaran, nilai rata-rata kesesuaian isi, bahasa, presentasi dan desain materi pembelajaran adalah 3,54 yang diklasifikasikan sebagai "sangat baik" dan "sesuai" untuk diterapkan. Selanjutnya, hasil penelitian ini menunjukkan bahwa materi pembelajaran membaca juga memenuhi kriteria bahan yang baik, misalnya, mengakomodasi perbedaan siswa. Dengan demikian, guru maupun penulis materi pembelajaran harus mengembangkan materi pembelajaran yang memfasilitasi kecerdasan majemuk siswa.
\end{abstract}

Kata kunci: bahan bacaan, perbedaan, kecerdasan ganda

\title{
INTRODUCTION
}

Reading is constituted as one of the most paramount language skills. This skill, indeed, plays a necessary role in language learning, academic 
achievement and career promotion. To illustrate, reading constructs human mind and boosts the students' vocabulary development and grammar knowledge. Meanwhile, in educational policies and practices, English reading comprehension has become the most significant issue (Slavin \& Cheung, 2005). In fact, there are a lot of learning resources printed in written text. Moreover, Odwan (2012) emphasizes that mastering reading is vital for academic success and achievement. In other words, the better reading skill, the better learning achievement attained. On account of this, reading becomes one of the main language skills taught in the teaching of English as a foreign language in Indonesian junior high school level due to the important role of reading and the status of English that has been dominantly used in international contexts.

In junior high school level, according to Permendikbud No 24 of 2016, students are envisaged to continually comprehend various written text types, for instance, determining the communicative purpose, the main idea and the rhetorical form of the text. However, Hamra \& Syatriana (2010) indicate that Indonesian students' reading comprehension is relatively low. In other words, students are not able to read with complete comprehension. Similarly, Suryanto (2017) argues that students tend to be passive during the process of teaching reading comprehension. Indeed, the students' passiveness influences the failure in reading (Johnston \& Winograd, 1985). In line with Suryanto, Abrar (2016) asserts that without any sufficient reading materials, learners surely feel difficulty in both comprehending the lesson and practicing reading. However, due to the shortage of teacher training, English teachers also face difficulty to design reading materials that suit their classes (Songbatumis, 2017). Meanwhile, the current English textbook arranged by the Ministry of Education and Culture mainly focuses on listening and speaking skills (Lisdayanti, 2018). As a result, students need more help and attention to succeed their teaching and learning.

One of the efforts to help students practice reading comprehension is designing reading materials that accommodate the learners' differences. One of the learners' differences catered in the current learning paradigm, learnercentered, is their multiple intelligent types. According to the multiple intelligence theory, Gardner in Armstrong (2009, p. 6) introduces at least eight intelligence types that individuals possess namely linguistic, logicalmathematical, spatial, bodily- kinaesthetic, musical, interpersonal, intrapersonal and naturalistic intelligence. Halley (2004) studies that the challenge in education is to create learning environments that cater to the development all intelligence types. However, only linguistic and logicalmathematical intelligence types are mostly fostered in the current process of teaching and learning. To illustrate, the teacher only gives instruction to read the text followed by answering the questions monotonously. Indeed, such 
kind of practice does not accommodate the other intelligence types. In fact, the Act No 20 of 2003 under article 4 states that education must be organized in the fair way which means all students' differences including multiple intelligence types must be catered. In a similar vein, Mostafa (2017) investigates the effect of implementing multiple intelligence theory for teaching reading comprehension.

The findings of his research show that learners taught by using multiple intelligence gain higher score than those who were taught through the conventional way of teaching. In line with Mostafa, Alqatanani (2017) also studies the effectiveness of using multiple intelligence for teaching reading of which result proves that multiple intelligence is effective for teaching reading.

In addition, Derakhsan \& Faribi (2015) report the impact of implementing multiple intelligence theory in the daily classroom that implementing multiple intelligence theory boosts up the students' motivation in language learning because they are able to use their strength in accomplishing the tasks and strengthen the other intelligence types. Moreover, McKenzie (2005, p. 6) poses that multiple intelligence types are necessary catered because Gardner's theory in multiple intelligence has address the needs for in $21^{\text {st }}$ life, such as, information technology skills, information literacy skills, problem-solving skills, collaboration skills, flexibility and creativity.

Therefore, to contribute in the development of the teaching English as a foreign language practices in Indonesia, this research is aimed at developing reading materials based on the students' multiple intelligence types for junior high school students of which results can be used as a reference for English teacher and as an insight for materials develop when they adapt and develop learning materials.

\section{LITERATURE REVIEW}

\section{A. Reading Comprehension}

As aforementioned earlier, reading is one of the most important language skills because reading constructs a human's mind. Basically, reading is defined as the language skill enabling the learners to derive meaning from the medium of print. Sugirin (2002) in his study mentions that reading entails the readers' effort to comprehend the text with the help of their prior knowledge to obtain approximate interpretation with the writer's intention. In line with Sugirin, Duffy $(2009$, p. 16) argues that $50-60 \%$ of successful comprehension is tied to the readers' prior knowledge. Referring to the general concept of 
reading, it can be concluded that reading belongs to an active skill elaborating word identification and interpreting. Harmer (2001, p. 70) summarizes that reading is not a passive skill requiring skills to be considered as an effective reader.

There are reading macro- and micro-skills that readers need to do in order to successfully comprehend a written text. Brown $(2001$, p. 307) lists the macro-skills for reading, including: a) recognizing the communicative function of written texts, according to the form and the purpose, b) inferring context that is not explicitly stated by using prior knowledge, c) detecting the connection between the main ideas and supporting details, d) distinguishing between literal and implied meanings, e) determining the rhetorical forms of the text, $\mathrm{f}$ ) developing the reading strategies such as scanning, skimming and guessing the meaning.

Meanwhile, the micro-skills of reading include: a) recognizing the grammatical knowledge, b) retaining chunks of language of different lengths in short-term memory and c) determining the cohesive devices. In short, reading involves the interaction between the readers and the text that require the skills of reading to accomplish the complete comprehension.

In order to master the skills of reading, readers take account of the models of reading applied. The first type is bottom-up which basically views that reading is initiated at the bottom level of text structure to the larger unit, for instance, translating the sentences (Hedgecock \& Ferris, 2009). Top- down model, on the contrary, views reading involves an interaction between thought and written language with the prior knowledge support to make inferences (Goodman, 1967). However, Kazemi, Hosseini \& Kohandani (2013) suggest to apply both bottom- up and top-down simultaneously because an effective reader recognizing the word automatically and parsing the text.

\section{B. Teaching Reading}

In line with the notion of reading comprehension, the notion of reading comprehension has become the core and English teachers' priority in teaching English as a foreign language of which goal is to enable the students to read various text types. As is seen later, Harmer (2001, p. 78) proposes five principles behind the process of teaching reading that teachers must follow in order to encourage the students actively participate, namely, reading is incredibly an active process, students are to engaged with what they read, students have to be encouraged to respond the content of the text, prediction becomes the major factor in reading, and the reading task matches to the topic. The five principles are then used as a means of consideration to design the stages of teaching reading. 
Before embarking to the stages of teaching reading, Hedgecock \& Ferris (2009, p. 161) suggest implementing two types of reading, namely, intensive reading that enables students to comprehend the selected text by translating the text and extensive reading that allows students to read a great number of texts without any follow-up exercise. It is important to implement both intensive reading in the classroom and extensive reading as their self-learning because extensive also develop the students' reading comprehension (Alyousef, 2005).

The stages of teaching reading implementing intensive reading in the classroom consist of pre-reading, while-reading and post-reading. Generally speaking, pre-reading stage involves the process of setting the purpose of reading and activating the students' prior knowledge through previewing both the title and the illustration. Meanwhile, while reading stage allows the students to tackle the text through incorporating the text information, linguistic knowledge and prior knowledge (Alyousef, 2006). The examples of while-reading activities are predicting, arguing the text within the students' experience and responding based on the text. After the students have read and comprehended the essential content presented in while-reading stage, they come to the final stage, post-reading stage. Hedgecock a\& Ferris (2009, p. 184) concluded that this stage should allow the students to evaluate and extend what they have learned in the previous stage by accomplishing the reading tasks. It can be concluded, an attempt to make the learning meaningful and to help the students interesting in the process of teaching reading, teachers must provide a variety of learning tasks that accommodate the students' differences that happen in the class.

\section{Multiple Intelligence}

During the last three decades, multiple intelligence has attracted scholars and researchers to investigate the impact of implementing this theory for teaching and learning in the classroom. Moreover, this theory challenges the notion of intelligence as a single number that is measured through a test that students have never learned before. According to Gardner in McKenzie (2005, p. 12) summarizes that individual must possess eight intelligence types, namely, linguistic as the ability to use language both orally and written, logical-mathematical as the ability to use number and to reason, visual as the ability to promote spatial reasoning, musical as the ability to perceive musical form, bodily- kinaesthetic as the ability to use body in skilled way, interpersonal as the ability to interact with others, intrapersonal as the ability to understand oneself and naturalist intelligence as the ability to specify numerous species in individual's environment. 
In fact, all intelligence types must be addressed and valued in the teaching and learning process. So that, all students are able to use their strength to meaningfully participate in the teaching and learning. Armstrong (2009) summarizes the four points why implementing multiple intelligence theory is suitable: a) each individual possesses all intelligence types, b) intelligence types can be developed, c) intelligence types work together in complex ways which means that no intelligence types that exists by itself in life and d) there are many different ways to be intelligent through a variety sets of tasks. In addition, this theory opens door to a variety of learning tasks to promote the students' motivation and to overcome their boredom due to the monotonous ways of teaching. Therefore, implementing multiple intelligence theory for teaching reading is necessary. One of the efforts to help teachers implement this theory is by designing reading materials based on the students' multiple intelligence types.

In the context of teaching reading, students' multiple intelligence types are catered through a variety set of tasks, such as, question and answer to accommodate the students' linguistic intelligence, comparing and contrasting the text to accommodate the students' logical-mathematical intelligence, exploring the pictures and matching the pictures to the sentences to accommodate the students' visual intelligence, role-playing and searching a text from the internet or book to accommodate the students' bodilykinaesthetic intelligence, reading a song lyric to accommodate the students' musical intelligence, group-working to accommodate the students' interpersonal intelligence, self-assessment and defining the purpose of reading to accommodate the students' intrapersonal intelligence and exploring to various texts about nature to accommodate the students' naturalistic intelligence. To conclude, designing reading materials based on multiple intelligence, different tasks must be presented so that students experience to use their strength to complete the tasks resulting in meaningful learning.

\section{Material Development}

Tomlinson (1998, p. 2) define materials development as the efforts conducted by material writers and teachers to provide sources of language input. Indeed, there are criteria that must be followed in designing learning materials, involving: a) materials should be relevant and adequate to achieve the competencies that must be suitable to the basic competence stated in Permendikbud No 24 of 2016 b) materials should achieve impact through novelty and appealing content, such as, unusual and various topics and tasks c) materials should help the students feel at ease, such as, presenting the texts that students are familiar with the topic, d) materials should help learners develop confidence, and e) materials should facilitate students' self-learning. 
In addition, Masuhara in Tomlinson (2013, p. 366) describes that materials writers and teachers must pay attention to the major approaches to teaching reading materials including the reading comprehension-based approach that facilitate students to practice reading comprehension, the language-based approach that exposes the students' vocabulary, the skillsbased approach that enormously enables the students to apply reading skills and the schema-based approaches that stimulate the students to discuss their own experience related to the topic of the text.

\section{METHOD}

The purpose of this research is to develop reading materials based on the students' multiple intelligence types and to investigate the appropriateness of the reading materials according to the expert's review, the students and the teacher's responses. This research belonging to research and development adapts the model of research and development by Gall, Gall \& Borg (2007, p. 590) since this model is considered as the most comprehensive among the other models because this model includes ten step, namely, a) assessing needs to identify the goals, b) conducting instructional analysis, c) analyzing learners and context, d) writing performance objectives, e) developing assessment instruments, f) developing instructional strategy, g) developing and selecting instructional materials, h) designing and conducting evaluation, i) revising the instruction and $\mathrm{j}$ ) designing and conducting evaluation. However, due to the limited time, Gall, Gall \& Borg (2007, p. 575) suggest to adapt the steps of the research. Therefore, the researcher adapts six steps to develop the educational product including conducting needs analysis, developing the course grid, developing the prototype of reading materials based on multiple intelligence, conducting expert judgement, trying out the prototype and revising the prototype.

In order to find out the students' needs concerning with the necessities, lacks and wants and to investigate the appropriateness of the reading materials, the researcher distributed sheets of questionnaire. During the needs analysis process, the researcher investigated the students' needs in three junior high schools in Magelang. Meanwhile, for subject try-out, eighth grade students of SMP 1 Windusari were chosen by purposive sampling because the students were still learning the materials that were being developed. The results of needs analysis were used as the consideration to develop the reading materials. After the materials were developed, the materials were validated to evaluate the materials before being tried out. During the process of try-out, the researcher also distributed sheets of questionnaire to investigate the students' opinion about the reading materials. The questionnaire used Likert 
Scale consisting of four responses namely "strongly agree, agree, disagree and strongly disagree". The questionnaire, the instrument of this research was validated by submitting the blueprint of the questionnaire to the expert. The expert who is the lecturer of English Education of Graduate School, Yogyakarta State University gave comments on the content, the language and the layout of the questionnaire.

After the data is obtained, the data is then analysed by using descriptive statistics to describe the data (Sugiyono, 2007). After calculating the percentage of the score, the mean of the score was then categorized into "very good, good, fair or poor" (Wagiran, 2013).

\section{RESULTS AND DISCUSSIONS}

The results of this research are divided into three parts, namely, the result of the needs analysis, the result of expert judgement and the result of try-out. According to the result of the needs analysis, students still faced the difficulty in reading comprehension and lack of vocabulary development and grammar knowledge. To illustrate, they got difficulty to determine the main idea and the communicative function of a text. Indeed, the lack of reading materials that suit to their needs mainly caused this problem. Thus, they expected to have materials that include a variety of reading tasks accommodating their multiple intelligence types, such as, matching task, word order, roleplaying, learning through a song lyric, group working and searching their preference text. Interestingly, reading tasks that cater the students' musical and bodily-kinesthetic intelligence types are the least expected.

The materials developed consisted of six units namely, Will You Join Us?, My Cat is Lovely, What did You Do Yesterday?, Attention, Please, Once Upon a Time and We Have a Lot of Dreams. The first unit, Will You Join Us mainly talks about short functional texts, invitation and greeting cards. The tasks presented mainly cater the students linguistic and logical-mathematical tasks in the form of question -answer, inferring the meaning of the text, comparing and contrasting two texts.

The second unit, My Cat is Lovely mainly discusses descriptive text. Generally, the tasks presented in this unit cater visual and interpersonal intelligence types in the form of exploring the pictures and group working. The third unit is What did You Do Yesterday? Discusses recount text accompanied with various tasks that mainly cater the students' linguistic, logical-mathematic and bodily-kinesthetic intelligence types in the form of word search, arranging the sentences and roleplaying. 
The fourth unit is Attention, Plaese talking about short functional text announcement and short message. The tasks in this chapter mainly foster the students' linguistic and interpersonal intelligence types in the form of guessing the meaning from the context and pair work. The fifth unit is Once Upon a Time discussing narrative texts. The tasks in this unit mainly cater the students' visual, bodily-kinesthetic, interpersonal, intrapersonal and naturalistic intelligence types in the form of matching the pictures and the sentences, watching video of a fable, roleplaying, retelling the moral values of the students' favourite fable. The last unit is We Have a lot of Dreams that mainly cater the students' musical intelligence types because this chapter enables students comprehend reading text in the form of song lyrics. However, it was quite time-consuming to develop reading materials based on the students' multiple intelligence because the researcher had to carefully select and design the appropriate tasks. Therefore, the researcher also provided the map of multiple intelligence-based tasks in the beginning of every unit so that the teachers are able to select or adapt the reading tasks that are suitable to their students.

Meanwhile, the results of expert judgement and try-out of the prototype showed that the reading materials, entitled "A Smart Way to Read" are appropriate to implement. The materials were evaluated concerning the appropriateness of the content, the language, the presentation and the design. The evaluation was adapted from Badan Standar Penilaian Nasional. The mean score for the appropriateness of the book according to the media and material expert was 3.34 which was considered as "very good". The media and material expert gave comment to add various reading tasks and to state the learning objectives clearly.

According to the students' and teacher's responses, the mean score of the appropriateness of the materials was 3.54 which was also considered as "very good" and appropriate to be implemented. In addition, according to the students' response, the tasks presented were interesting. All students meaningfully learn and participate during the process of teaching reading since their strength was appreciated. In line with the results of this research, Spirovska (2013) adds that the importance of the implementation of multiple intelligence theory is that it gives students an opportunity to use their predominant strengths in order to foster learning. Therefore, the students respond that reading materials based on the students' multiple intelligence were appropriate to implement. Furthermore, Halley (2004) studies that implementing multiple intelligence theory creates a positive influence for both the teacher and the students. To conclude, implementing reading materials based on the students' multiple intelligence offers a huge variety of learning tasks to interest the students to actively participate in learning which results in the better readiness and achievement in learning. Additionally, this 
254 Celt: A Journal of Culture, English Language Teaching \& Literature, Volume 19, Number 2, December 2019, pp. 244- 256

research gives insightful ways for the teacher to develop learning materials based on multiple intelligence types.

\section{CONCLUSION}

In line with the result of this research, the reading materials based on the students' multiple intelligence were appropriate to implement. Furthermore, these materials were expected to overcome the students' boredom due to the monotonous ways of teaching and to interest them participating during the teaching and learning since they lack of reading materials that accommodate their multiple intelligence types as catered in nowadays learning paradigm assigning that every student is unique. As aforementioned earlier, the current reading materials for junior high school students contain neither various texts nor tasks that accommodate the students' differences. Previously, the results indicate that reading materials based on the students' multiple intelligence were appropriate to implement in term of the content, the language, the presentation and the graphic. Thus, it is suggested for the teachers and other stakeholders to continuously conducting learning materials that accommodate the students' multiple intelligence types. However, this research still has the limitation that the materials have not been investigated the effectiveness. Therefore, for the further research, the effectiveness of implementing reading materials based on the students' multiple intelligence needs to be investigated.

\section{REFERENCES}

Abrab, M. (2016). Teaching English Problems: An analysis of EFL primary school teachers in Kuala Tangkal. The Proceedings of the $16^{\text {th }}$ Indonesian Scholars International Convention, 94 - 101.

Alqatanani, A.K. (2017). Do multiple intelligence improve EFL students' critical reading skills?. Arab World English Journal, 8(1), 309-321.

Alyousef, H.S. (2005). Teaching Reading Comprehension to EFL Learners. The Reading Matrix, 5 (2), 143- 154.

Armstong, T. (2009). Multiple Intelligence in the Classroom. Virginia: ASCD.

Brown, H.D. (2001). Teaching by Principles: An interactive approach to language pedagogy. New York: Longman Inc. 
Student's Multiple Intelligence Types for Junior High School Students Writing

Derakhsan, A. \& Faribi,M .(2015). Multiple intelligence: Language learning and teaching. International Journal of English Linguistics, 5(4), 63-72.

Duffy, G.G. (2009) Explaining Reading: A resource for reaching concepts, skills and strategies. New York: The Guilford Press.

Gall, M., Gall, J., \& Borg, R. (2007). Educational Research: An introduction ( $\left.8^{\text {th }} \mathrm{ed}\right)$. New York: Pearson Education.

Goodman, K. S. (1967). Reading: A psycholinguistic guessing game. Journal of the Reading Specialist, 6, 126 - 135.

Halley, M. H. (2004). Learner-Centered Instruction and the Theory of Multiple Intelligences with Second Language Learners. Teacher College Record, 106(1), 163-180.

Hamra, A. \& Syatriana, E. (2010). Developing a Model of Teaching Reading Comprehension for EFL Students. TEFLIN Journal, 21 (1), 27 - 40.

Harmer, J. (2001). How to Teach English. Edinburgh: Pearson Education Limited.

Hedgecock, J.S. \& Ferris, D.R. (2009) Teaching Readers of English: Students, texts and context. New York: Routledge.

Johnston, P.H \& Winograd, P.N. (1985). Passive failure in reading. Journal of Reading Behavior, 17 (4), 279 - 301.

Kazemi, M., Hosseini, M. \& Kohandani, M. (2013). Strategic reading instruction in EFL context. Theory and Practice in Language Studies, 3(12), 2333-2342.

McKenzie, W. (2005). Multiple Intelligences and Instructional Technology. Wahington: ISTE.

Mostafa, A.A. (2017). The Effect of Using Multiple Intelligences on Some Basic Reading Skill of First Graders At- Risk for Reading Disabilities. International Journal of Educational Psycho-Educational Science, 6 (3), $109-116$.

Odwan, T.A. (2012). The Effect of the Directed Reading Thinking Activity through Cooperative Learning on English Secondary Stage Students' Reading Comprehension in Jordan. International Journal of Humanities and Social Science, 2(16), 138 - 151. 
256 Celt: A Journal of Culture, English Language Teaching \& Literature, Volume 19, Number 2, December 2019, pp. 244- 256

Slavin, R.E \& Cheung, A. (2005). A Synthesis of Research on Language Reading Instruction for English Language Learners. Review of Educational Research Summer, 75 (2), 247 - 284.

Songbatumis, A.M. (2017). Challenges in teaching English faced by English techers at MTsN Taliwang, Indonesia. Journal of Foreign Language Teaching E Learning, 2(2), 54 - 67.

Spirovska,E. (2013). Integrating Multiple Intelligences in Teaching English as a Foreign Language. South East European University Review, 9 (1), 1-12.

Sugirin. (2002). The Comprehension Strategies of Above Average English as a Foreign Language Readers. Dissertation, Deakin University.

Sugiyono. (2017). Metode Penelitian Pendidikan: Pendekatan kuantitatif, kualitatif fan R\&D. Bandung: Alfabeta.

Suryanto. (2017). An investigation on English reading comprehension problems in Indonesial cultural contexts. The $1^{\text {st }}$ International Conference on Education, Science, Art and Technology, 200-206.

Tomlinson, B. (1998). Materials development in language teaching. Cambridge: Cambridge University Press.

Tomlinson, B. (2013). Developing materials for language teaching. New York: Bloomsbury.

Wagiran. (2013). Metodologi Penelitian Pendidikan: Teori dan Implementasi. Yogyakarta: Deepublish. 